\title{
Extending Lactation in Pasture-Based Dairy Cows: I. Genotype and Diet Effect on Milk and Reproduction
}

\author{
E. S. Kolver, ${ }^{1,2}$ J. R. Roche, C. R. Burke, J. K. Kay, and P. W. Aspin \\ Dexcel, Private Bag 3221, Hamilton, New Zealand
}

\section{ABSTRACT}

The aim of this study was to test the feasibility of extended lactations in pastoral systems by using divergent dairy cow genotypes [New Zealand (NZ) or North American (NA) Holstein-Friesian (HF)] and levels of nutrition $(0,3$, or $6 \mathrm{~kg} / \mathrm{d}$ of concentrate dry matter). Mean calving date was July 28, 2003, and all cows were dried off by May 6, 2005. Of the 56 cows studied, 52 (93\%) were milking at $500 \mathrm{~d}$ in milk (DIM) and $10(18 \%)$ were milking at 650 DIM. Dietary treatments did not affect DIM (605 \pm 8.3 ; mean \pm SEM). Genotype by diet interactions were found for total yield of milk, protein, and milk solids (fat + protein), expressed per cow and as a percentage of body weight. Differences between genotypes were greatest at the highest level of supplementation. Compared with NZ HF, NA HF produced $35 \%$ more milk, $24 \%$ more milk fat, $25 \%$ more milk protein, and at drying off had 1.9 units less body condition score ( 1 to 10 scale). Annualized milk solids production, defined as production achieved during the 24-mo calving interval divided by $2 \mathrm{yr}$, was $79 \%$ of that produced in a normal 12-mo calving interval by NZ HF, compared with $94 \%$ for NA HF. Compared with NZ HF, NA HF had a similar 21-d submission rate $(85 \%)$ to artificial insemination, a lower 42 -d pregnancy rate (56 vs. $79 \%$ ), and a higher final nonpregnancy rate (30 vs. $3 \%$ ) when mated at $451 \mathrm{~d}$ after calving. These results show that productive lactations of up to $650 \mathrm{~d}$ are possible on a range of pasture-based diets, with the highest milk yields produced by NA HF supplemented with concentrates. Based on the genetics represented, milking cows for $2 \mathrm{yr}$ consecutively, with calving and mating occurring every second year, may exploit the superior lactation persistency of high-yielding cows while improving reproductive performance.

Key words: genotype, supplement, extended lactation, pasture

\footnotetext{
Received April 30, 2007.

Accepted August 8, 2007.

${ }^{1}$ Corresponding author: eric.kolver@synlait.co.nz

${ }^{2}$ Present address: Synlait Ltd., Waikato Innovation Park, Ruakura Road, PO Box 9466, Hamilton, New Zealand.
}

\section{INTRODUCTION}

Dairy systems based on lactations of 2 yr or more have been proposed as an alternative to typical 305-d lactations (Knight, 1998; Rotz et al., 2005). Simulation modeling indicates that such systems can provide longterm economic and environmental benefits relative to traditionally managed farms, provided annual milk production per cow is within $7 \%$ of traditional farms and average lactation length is 3 or more years (Rotz et al., 2005).

For commercial application of these "perennial cow" systems, specialized management and genetic selection strategies need to be developed. Management options that have been tested with calving intervals ranging from 12 to 18 mo include a planned increase in calving interval (Knight, 1998; Rehn et al., 2000; Arbel et al., 2001) in conjunction with the use of bST (Van Amburgh et al., 1997) or increased milking frequency (Osterman and Bertilsson, 2003).

To date, the impact of nutrition on extended lactations has not been quantified, with most controlled studies of extended lactation having been conducted in similar confinement feeding systems. The application of extended lactations to lower producing farm systems was reviewed by Borman et al. (2004), who contended that extended lactations could be a suitable option for some pasture-based systems, but that this would depend on cow milk production potential, ability to grow pasture or feed supplements economically, management capability, environmental constraints, herd size, and labor availability. Recently, Auldist et al. (2007) reported no penalty in fat and protein yields when lactation in pasture-based dairying systems was extended from 10 to $16 \mathrm{mo}$, and only a small penalty (5 to 7\%) when lactations were extended to 19 and $22 \mathrm{mo}$.

Expected benefits of extended lactations, compared with 12-mo seasonally calving systems, include a reduced number of days dry within the lifetime of the cow; reduced per-cow costs associated with mating, calving, animal health, and cow replacement; a more even spread of labor requirements, input costs, and income throughout the year (Borman et al., 2004); and improved animal well-being through reduced metabolic 
stress, exposure to fewer periods of high risk, and increased longevity (Knight, 1998). Fundamental changes in the ability of the modern cow to continue producing at high yield for a much longer proportion of lactation, and consequent low fertility (Thatcher et al., 2006), have been a primary driver of interest in extended lactation.

Additional costs may be incurred with extended lactations, such as fewer replacement heifers being available and lower utilization of pasture during the second year, when cows have lower milk yields. Nonetheless, reduced cow wastage and improved fertility under extended lactations may reduce the requirement for replacement heifers, and alternative management systems, such as calving one-half the herd every second year, may be developed to maintain pasture utilization.

The present study tested the ability of cows grazing pasture to achieve 670-d lactations when calving every $2 \mathrm{yr}$. The first objective was to quantify the impact that level of nutrition had on achieving long lactations. Because previous pasture-based studies showed an interaction between level of nutrition and cow genotype (Horan et al., 2005; Kolver et al., 2002; Roche et al., 2006), the second objective was to compare the performance of Holstein-Friesian (HF) cows of New Zealand (NZ) or North American (NA) origin in a 24-mo calving interval system.

\section{MATERIALS AND METHODS}

\section{Design}

Sixty NA HF $(\mathrm{n}=30)$ and NZ HF $(\mathrm{n}=30)$ cows grazed pasture and were fed 0,3 , or $6 \mathrm{~kg} / \mathrm{d} \mathrm{DM}$ of a pelleted concentrate supplement [60\% corn grain, $31 \%$ barley grain, $7 \%$ molasses, and $2 \%$ broll (wheat bran and pollard) on a DM basis] at the Dexcel Lye Dairy, New Zealand $\left(37^{\circ} 46^{\prime} \mathrm{S}, 175^{\circ} 18^{\prime} \mathrm{S}\right)$ from June 2003 to May 2005. All procedures had prior approval of the Ruakura Animal Ethics Committee, New Zealand. Cows were allocated to 1 of 6 feeding treatments (NZ0, NZ3, NZ6, NA0, NA3, NA6) based on genotype and breeding worth (a measure of genetic merit accounting for the economic value of the trait; Harris et al., 1996), and within genotype treatments were balanced for BW and expected calving date.

Of the 60 cows that began the study, 1 cow died from milk fever within a week of calving (NA0), 1 cow died from a lung abscess within 2 wk of calving (NA3), 1 cow was removed after 5 mo following an Escherichia coli infection (NZ3), and 1 cow was removed after 9 mo based on milking temperament (NA0). Data from these cows were excluded from analysis.

New Zealand HF and NA HF had a breeding worth of $124 \pm 31$ (mean $\pm \mathrm{SD}$ ) and $116 \pm 37$, respectively; a calving BW of $587 \pm 70$ and $700 \pm 98 \mathrm{~kg}$, respectively; a calving date of July 26, $2003 \pm 26 \mathrm{~d}$ and August 1, $2003 \pm 26 \mathrm{~d}$, respectively; an age of 5.8 and $5.7 \pm 1.70$ yr, respectively; and were composed of 28 and $26 \%$ firstand second-lactation cows, respectively, with mixedage cows ranging from third to sixth lactation. Cows in the dietary treatments 0,3 , and $6 \mathrm{~kg} / \mathrm{d}$ of DM had a breeding worth of $125 \pm 39,119 \pm 27$, and $117 \pm 35$, respectively; a calving BW of $641 \pm 93,647 \pm 88$, and $641 \pm 116 \mathrm{~kg}$, respectively; a calving date of July 24, $2003 \pm 26 \mathrm{~d}$, August 7, $2003 \pm 23 \mathrm{~d}$, and July 23, 2003 $\pm 25 \mathrm{~d}$, respectively; an age of $5.8,5.6$, and $5.9 \pm 1.70$ yr, respectively; and were composed of 33,39 , and $25 \%$ first- and second-lactation cows, respectively, with mixed-age cows ranging from third to sixth lactation.

\section{Cow Selection}

The cows were sourced from previous genotype comparison experiments conducted at Dexcel (Kolver et al., 2002, 2005; Roche et al., 2006), and the numbers of cows analyzed per treatment are presented in Table 1. The 2 genotypes compared were either of predominantly (>87.5\%) NA HF or NZ HF ancestries, based on 3 -generation pedigrees, and were represented in each dietary treatment by common sires (NZ0, 7 sires; NZ3, 6 sires; NZ6, 5 sires; NA0 5 sires; NA3, 7 sires; NA6, 9 sires).

The multiparous NA HF cows were either imported as embryos in 1996 from the United States and the Netherlands by Holland Genetics Ltd. for Livestock Improvement Corporation (LIC) Ltd. (Hamilton, NZ) as part of the LIC sire-proving scheme, or were direct descendents of the embryos imported. As such, the NA $\mathrm{HF}$ genetics used in the present experiment all had NZ proofs and represented NA HF genetics that have been used widely in grazing systems. The sires had been used in other larger genotype studies representing NZ $\mathrm{HF}$ and NA HF genetics (Harris and Kolver, 2001; Horan et al., 2005; Macdonald et al., 2007). North American calves were sold to commercial farmers and were subsequently purchased by Dexcel Ltd. before their first parturition. The primiparous NA HF were bred in New Zealand by using NA HF sires available in New Zealand.

The EBV of animals were obtained from LIC evaluations (May 2005; LIC). The EBV of NA HF were 1,275 $\pm 223.7 \mathrm{~kg}$ of milk, $35 \pm 7.0 \mathrm{~kg}$ of fat, $40 \pm 6.4 \mathrm{~kg}$ of protein, $91 \pm 9.4 \mathrm{~kg}$ of $\mathrm{BW},-4.3 \pm 2.4 \%$ fertility, and $-227 \pm 97.2 \mathrm{~d}$ residual survival.

The NZ HF genetics were selected from Dexcel Ltd. herds based on their breeding worth and the proportion of NZ HF ancestry ( $<12.5 \%$ NA HF genes). The EBV of NZ HF were $867 \pm 199.9 \mathrm{~kg}$ of milk, $30 \pm 7.1 \mathrm{~kg}$ of fat, 
Table 1. Cows per treatment, mean calving date, proportion of the herd milking at final dry-off ( $649 \pm 11$ DIM from mean calving date), and concentrate intake of New Zealand (NZ) and North American (NA) Holstein-Friesians grazing pasture and fed 0, 3, or 6 kg/d of concentrate DM during extended ${ }^{1}$ lactation

\begin{tabular}{|c|c|c|c|c|c|c|c|c|c|c|}
\hline \multirow[b]{2}{*}{ Item } & \multicolumn{6}{|c|}{ Treatment $^{2}$} & \multirow[b]{2}{*}{$\mathrm{SED}^{3}$} & \multicolumn{3}{|c|}{$P$-value } \\
\hline & NZ0 & NZ3 & NZ6 & NA0 & NA3 & NA6 & & Genotype & Diet & $\mathrm{G} \times \mathrm{D}^{4}$ \\
\hline Cows per treatment & 10 & 9 & 10 & 8 & 9 & 10 & & & & \\
\hline Milking at final dry-off, $\%$ of herd & 20 & 22 & 0 & 38 & 56 & 50 & & & & \\
\hline Concentrate & & & & & & & & & & \\
\hline $\mathrm{kg} / \mathrm{d}$ of $\mathrm{DM}$ & & 2.99 & 5.51 & & 3.00 & 5.71 & 0.097 & NS & $<0.001$ & NS \\
\hline $\mathrm{kg} /$ lactation & & 1,817 & 3,123 & & 1,802 & 3,611 & 146.9 & 0.05 & $<0.001$ & $<0.05$ \\
\hline
\end{tabular}

${ }^{1}$ The period from calving to actual dry-off date in a 24-mo calving interval system.

${ }^{2}$ Treatment: NZ0 = NZ cows fed $0 \mathrm{~kg} / \mathrm{d}$ of concentrate DM; NZ3 = NZ cows fed $3 \mathrm{~kg} / \mathrm{d}$ of concentrate DM; NZ6 = NZ cows fed $6 \mathrm{~kg} / \mathrm{d}$ of concentrate DM; NA0 = NA cows fed $0 \mathrm{~kg} / \mathrm{d}$ of concentrate DM; NA3 = NA cows fed $3 \mathrm{~kg} / \mathrm{d}$ of concentrate DM; NA6 = NA cows fed $6 \mathrm{~kg} / \mathrm{d}$ of concentrate DM.

${ }^{3}$ Standard error of the difference.

${ }^{4}$ Genotype $\times$ diet interaction.

$31 \pm 6.1 \mathrm{~kg}$ of protein, $54 \pm 12.2 \mathrm{~kg}$ of BW, $0.4 \pm 2.0 \%$ fertility, and $7 \pm 66.5 \mathrm{~d}$ residual survival.

\section{Feeding and Management}

Cows with electronic identification were individually fed supplement at each milking in a rotary dairy. A flat rate of 0,3 , or $6 \mathrm{~kg} / \mathrm{d}$ of $\mathrm{DM}(0,3.5$, or $7 \mathrm{~kg} / \mathrm{d}$ of fresh matter) was fed each day of lactation, with individual residues being measured and sampled at each milking. Thus, this experiment was a lactation-long comparison of 3 pasture-based diets, rather than a farm systems experiment. The $6 \mathrm{~kg} / \mathrm{d}$ of DM level of supplementation (14.0 MJ of ME/kg of DM; $11.5 \% \mathrm{CP} ; 9.5 \% \mathrm{NDF} ; 4.2 \%$ $\mathrm{ADF}$ ) was considered the highest rate that could be fed with high-quality pasture (11.9 MJ of ME/ $\mathrm{kg}$ of DM; $23.5 \% \mathrm{CP} ; 41.5 \% \mathrm{NDF} ; 22.1 \% \mathrm{ADF}$ ) without incurring protein or fiber deficiencies in the diet. Supplemented cows were offered $2 \mathrm{~kg} / \mathrm{d}$ of DM for $15 \mathrm{~d}$ prior to calving, with the feeding rate rising to $3 \mathrm{~kg} / \mathrm{d}$ of DM immediately after calving for the $3 \mathrm{~kg} / \mathrm{d}$ of DM treatments, and to 6 $\mathrm{kg} / \mathrm{d}$ of DM gradually over the first week for the $6 \mathrm{~kg} /$ $\mathrm{d}$ of DM treatments. Cows received $12 \mathrm{~g} / \mathrm{d}$ of supplementary magnesium via the water trough pre- and postcalving, and an additional $12 \mathrm{~g} / \mathrm{d}$ of magnesium as a drench postcalving until November, as well as during the second spring. Cows received a calcium drench $(50 \mathrm{~g}$ of $\mathrm{Ca})$ on the day of calving.

Cows were grazed as one herd to ensure that a common pasture allowance $(50 \mathrm{~kg} / \mathrm{d}$ of DM) was achieved for all treatments and so that cows could be used as replicates. Cows were grazed on 20 ha of land (twenty, 1-ha paddocks), but this was not a closed system, with pasture quality being maintained by a following nontreatment herd or mechanical cutting as needed during spring. Postgrazing residuals were used to determine pasture allocation by using calibrated visual assessment; $1,800 \mathrm{~kg}$ of $\mathrm{DM} / \mathrm{ha}$ was targeted during spring and autumn, and 2,200 to $2,400 \mathrm{~kg}$ of $\mathrm{DM} / \mathrm{ha}$ was targeted during summer. The herd rotated through paddocks every $21 \mathrm{~d}$ in spring, summer, and autumn, and every $60 \mathrm{~d}$ during winter (June), which was reduced to $40 \mathrm{~d}$ in early spring (August). A total of $846 \mathrm{~kg}$ of grass silage $\mathrm{DM} /$ cow (11.1 MJ of ME/kg of DM; $18.2 \% \mathrm{CP}$; 47.6\% NDF; $32.1 \%$ ADF) was calculated as consumed during the 2-yr lactation, and was fed for $37 \mathrm{~d}$ in August to September 2003 (3.6 kg/d of DM); 109 d from April to July 2004 (4 kg/d of DM); and $53 \mathrm{~d}$ from August to September $2004(5.9 \mathrm{~kg} / \mathrm{d}$ of DM) to maintain pasture residual targets.

Lactation length for the "normal" 12 -mo calving interval was calculated from the time of calving to a theoretical dry-off date based on BCS, time from calving, and daily milk production (Macdonald et al., 2005). Final dry-off date following the extended lactation was based on decisions outlined in Macdonald et al. (2005), with a final dry-off date imposed $52 \mathrm{~d}$ before the planned start of calving. Drying-off decisions for the rest of lactation were based on milk production $(<4 \mathrm{~kg}$ of milk/d for $2 \mathrm{wk} ;<5 \mathrm{~kg}$ of milk/d for 2 wk during the last 2 mo of lactation).

\section{Establishment of a 24-Mo Calving Interval}

Cows were mated over an 11-wk period beginning on September 25, 2003, $82 \mathrm{~d}$ after the start of calving. This provided information on reproductive performance in a normal 12-mo seasonal calving system. A whole-herd estrous synchronization program based on $\mathrm{Xu}$ et al. (1996) was used prior to a 4-wk period of AI, followed by 7 wk of natural mating. Cows that calved $<30 \mathrm{~d}$ before planned start of mating (PSM) were treated with 
an intravaginal progesterone insert (Eazi-Breed controlled internal drug-releasing intravaginal insert (CIDR); Pfizer, Auckland, New Zealand) for $8 \mathrm{~d}$. An injection of 1 or $2 \mathrm{mg}$ of estradiol benzoate (Cidirol, Bomas Laboratories Ltd., Auckland, New Zealand) was administered, with CIDR insertion for cows diagnosed as anestrus or cycling, respectively. All cows received an injection of $\mathrm{PGF}_{2 \alpha}$ analog $[2 \mathrm{~mL}$ of Estroplan and $500 \mu \mathrm{g}$ of cloprostenol, Parnell Laboratories (NZ) Ltd., Auckland, New Zealand] at the time of CIDR removal (d -2 PSM). All cows received an injection of $1 \mathrm{mg}$ of estradiol benzoate $24 \mathrm{~h}$ after CIDR withdrawal and were subsequently mated by $\mathrm{AI}$ on detection of estrus. All cows inseminated between d 0 and 2 PSM were resynchronized with the reinsertion of a previously used CIDR between $\mathrm{d} 15$ and 23 and an injection of 0.5 $\mathrm{mg}$ of estradiol benzoate $24 \mathrm{~h}$ after the used CIDR was removed. Cows with return estruses were mated accordingly. Cows ineligible for the initial synchronization program were treated at this same time, but using the protocol for initial synchronization as previously described.

To establish a 24-mo calving interval with these same animals, pregnancies detected by ultrasonography at 74,84 , or $112 \mathrm{~d}$ after PSM were terminated by prostaglandin treatment ( $2 \mathrm{~mL}$ of Estroplan) in accordance with the New Zealand Veterinary Code of Practice. The subsequent mating occurred on September 28, 2004, $451 \mathrm{~d}$ after the start of calving. Two ultrasonography examinations of the reproductive tract were performed $10 \mathrm{~d}$ apart prior to mating. These revealed healthy uteri by appearance and ovarian structures consistent with normal estrous activity in all but 4 cows. The latter ( 3 NA HF and 1 NZ HF) were diagnosed with cystic ovarian follicles and subsequently treated with a GnRHbased protocol by the attending veterinarian. All other cows were inseminated on detection of spontaneous estrus for the first $5 \mathrm{wk}$ and then naturally mated for 6 wk. Pregnancy diagnoses by ultrasonography were performed 77 and $128 \mathrm{~d}$ after the start of mating to confirm conception dates and final pregnancy rates.

\section{Measurements}

Individual milk yield was recorded at each milking (Westfalia Surge, Oelde, Germany). Milk composition was determined by infrared (Fourier-transform infrared spectroscopy FT120, Foss Electric, Hillerød, Denmark) on individual p.m. and a.m. 35-mL aliquot samples collected on $1 \mathrm{~d}$ weekly. Individual BW was assessed weekly during lactation, with BCS (1 to 10 scale; Macdonald and Roche, 2004) assessed weekly from calving until first mating, during the corresponding months of the extended phase of lactation, and every second week for the remainder of lactation. A representative 500-g sample of pregrazed pasture, and offered and refused concentrate were collected on $1 \mathrm{~d}$ weekly. Subsamples were oven-dried at $100^{\circ} \mathrm{C}$ for $24 \mathrm{~h}$, ground through a 0.5 -mm sieve, then analyzed for composition by near-infrared spectroscopy by a commercial laboratory (FeedTech, Palmerston North, New Zealand).

\section{Statistical Analysis}

All data were analyzed by using the REML procedure of Genstat (version 3.2). The $2 \times 3$ factorial design was analyzed by using a model that included genotype, linear and quadratic contrasts of diet, and linear and quadratic interactions as fixed effects, with sire and cow as random effects.

A "normal" lactation for each treatment was defined as the period from calving to the theoretical dry-off date (calculated as $296 \pm 23.6$ DIM). "Normal" reproductive performance refers to outcomes of the September 2003 breeding season, and "extended" reproductive performance refers to outcomes of the September 2004 breeding season. "Annualized" production was defined as the production achieved during the 24-mo calving interval divided by 2 yr to give an annual production.

Reproductive data were analyzed by using generalized linear models with binomial error distribution and logit link, including genotype, diet, and the interactions as fixed effects. Diet and genotype $\times$ diet interactions were not significant and have not been presented because low cow numbers per treatment make interpretation of reproductive results difficult.

Significant effects for all analyses were declared at $P$ $<0.05$. Significance levels for the genotype $\times \operatorname{diet}_{\text {Quadratic }}$ interaction are not presented because none was significant except for BW at drying off.

\section{RESULTS}

Both genotypes consumed all of the $3 \mathrm{~kg} / \mathrm{d}$ of concentrate DM offered, and $94 \%$ of the $6 \mathrm{~kg} / \mathrm{d}$ of concentrate DM offered. Because the NA HF fed $6 \mathrm{~kg} / \mathrm{d}$ of concentrate DM recorded more DIM than NZ HF, NA HF consumed more concentrate than NZ HF on the $6 \mathrm{~kg} /$ d of concentrate treatment. At final dry-off, twice as many NA HF were still in milk compared with NZ HF (Table 1).

\section{Normal Lactation}

In a normal 12-mo calving interval lactation (calculated as the period from calving to theoretical dry-off date), NA HF produced more $(P<0.05)$ milk $(7,539 \mathrm{vs}$. $6,615 \pm 4,62.2 \mathrm{~kg} / \mathrm{cow}$ ) and milk protein (261 vs. $238 \pm$ 
Table 2. Milk production and composition of New Zealand (NZ) and North American (NA) Holstein-Friesians grazing pasture and fed 0, 3 , or $6 \mathrm{~kg}$ of concentrate $\mathrm{DM} / \mathrm{cow}$ per d during normal ${ }^{1}$ and extended ${ }^{2}$ lactation

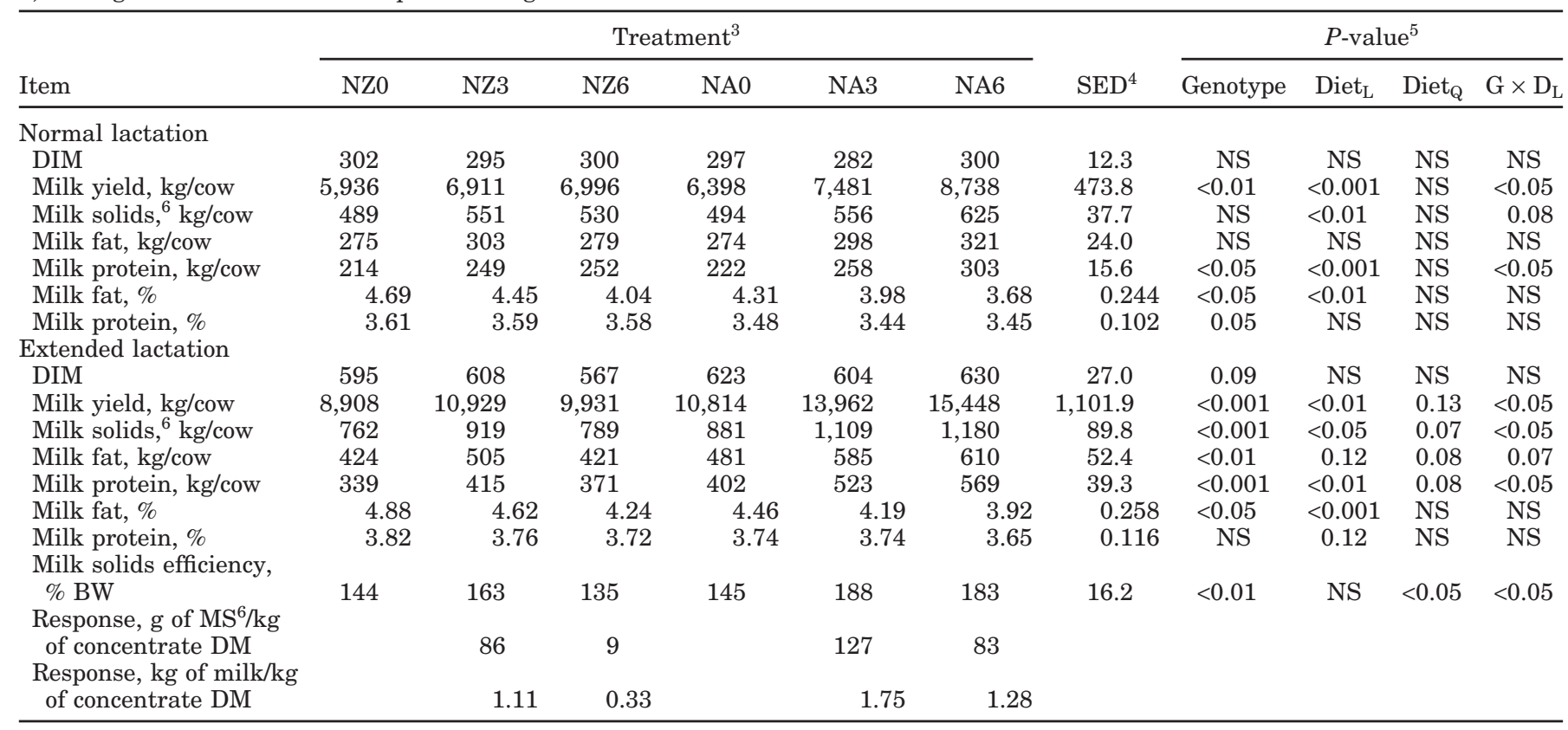

${ }^{1}$ The period from calving to the theoretical dry-off date in a 12 -mo calving interval system.

${ }^{2}$ The period from calving to actual dry-off date in a 24-mo calving interval system.

${ }^{3}$ Treatment: NZ0 = NZ cows fed $0 \mathrm{~kg} / \mathrm{d}$ of concentrate DM; NZ3 = NZ cows fed $3 \mathrm{~kg} / \mathrm{d}$ of concentrate DM; NZ6 = NZ cows fed $6 \mathrm{~kg} / \mathrm{d}$ of concentrate DM; NA0 = NA cows fed $0 \mathrm{~kg} / \mathrm{d}$ of concentrate DM; NA3 = NA cows fed $3 \mathrm{~kg} / \mathrm{d}$ of concentrate DM; NA6 = NA cows fed $6 \mathrm{~kg} / \mathrm{d}$ of concentrate DM.

${ }^{4}$ Standard error of the difference.

${ }^{5} \mathrm{~L}=$ linear contrast; $\mathrm{Q}=$ quadratic contrast; $\mathrm{G} \times \mathrm{D}=$ genotype $\times$ diet interaction.

${ }^{6}$ Milk solids (fat + protein) yield.

$11.2 \mathrm{~kg} / \mathrm{cow}$ ), the same amount of milk solids (fat + protein; 558 vs. $523 \pm 17.5 \mathrm{~kg} / \mathrm{cow}$ ), and milk with a lower $(P<0.05)$ percentage of fat $(3.99$ vs. $4.39 \pm 0.201 \%)$ and protein (3.46 vs. $3.59 \pm 0.068 \%$ ) compared with NZ HF. Supplementation with 0, 3, or $6 \mathrm{~kg} / \mathrm{d}$ of concentrate DM produced a linear increase $(P<0.001)$ in yields of milk $(6,167$ vs. 7,196 vs. $7,867 \pm 605.6 \mathrm{~kg} / \mathrm{cow}$, respectively), milk protein ( 218 vs. 253 vs. $277 \pm 21.1 \mathrm{~kg} / \mathrm{cow}$, respectively), and milk solids ( 492 vs. 554 vs. $577 \pm 31.3$ $\mathrm{kg} / \mathrm{cow}$, respectively) yield, and reduced $(P<0.01) \mathrm{milk}$ fat content $(4.50$ vs. 4.21 vs. $3.86 \pm 0.228 \%$, respectively), with no change in milk protein content (3.55 vs. 3.52 vs. $3.51 \pm 0.012 \%$, respectively). The genotype $\times$ diet $_{\text {Linear }}$ interaction indicated that the genotype differences in milk and protein yield were most pronounced $(P<0.05)$ at the highest level of concentrate (Table 2$)$.

\section{Genotype and Extended Lactation}

On all diets during the extended lactation resulting from a 24-mo calving interval, NA HF produced more $(P<0.001)$ milk with a lower $(P<0.05)$ percentage of milk fat and similar protein content, produced more $(P$
$<0.01$ ) milk solids expressed as kilograms per cow or as a percentage of $\mathrm{BW}$, gave a greater $(P<0.05)$ milk and milk solids response to concentrate, had a higher $(P<0.05) \mathrm{BW}$ at the start of lactation, gained less $(P$ $<0.001)$ BCS during lactation, and had lower $(P<0.001)$ BCS compared with NZ HF (Tables 2 and 3).

Of the 56 cows enrolled, $93 \%$ were milking at 500 DIM and $18 \%$ were milking at 650 DIM. Greater $(P<$ $0.05)$ proportions of the NA HF herd were still in milk at 500 DIM (100 vs. $86 \%$ ) and at 550 DIM (96 vs. $80 \%)$ compared with NZ HF, respectively, but differences were not significant at 600 DIM (74 vs. $62 \%$ ).

Compared with NZ HF in a normal lactation, NA HF had a lower $(P<0.01) 21$-d submission rate (the percentage of cows inseminated in the first $3 \mathrm{wk}$ of mating), a lower $(P<0.01) 42$-d pregnancy rate, and a higher $(P<0.01)$ final nonpregnancy rate. In the extended-lactation mating period, NA HF had a similar 21-d submission rate and first-service conception rate, a lower $(P<0.05) 42$-d pregnancy rate, and a higher $(P$ $<0.01$ ) final nonpregnancy rate compared with NZ HF (Table 4). During the normal lactation, there was no difference in BCS at planned start of mating between 
Table 3. Body weight and BCS at the start of lactation, and changes in BW and BCS between the start of lactation and dry-off, for New Zealand (NZ) and North American (NA) Holstein-Friesians grazing pasture and fed 0,3 , or $6 \mathrm{~kg} / \mathrm{d}$ of concentrate DM during extended ${ }^{1}$ lactation

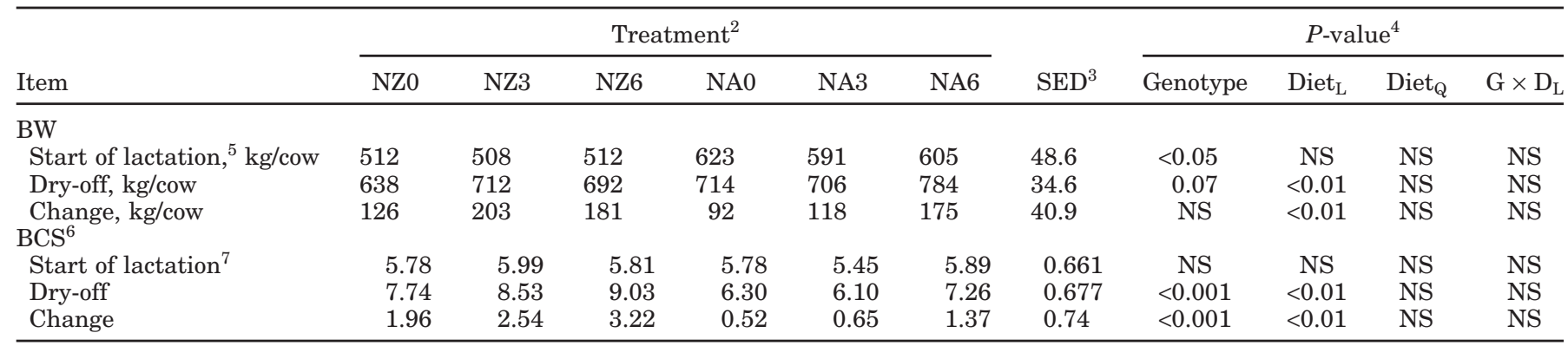

${ }^{1}$ The period from calving to actual dry-off date in a 24-mo calving interval system.

${ }^{2}$ Treatment: NZ0 = NZ cows fed $0 \mathrm{~kg} / \mathrm{d}$ of concentrate DM; NZ3 = NZ cows fed $3 \mathrm{~kg} / \mathrm{d}$ of concentrate DM; NZ6 = NZ cows fed $6 \mathrm{~kg} / \mathrm{d}$ of concentrate DM; NA0 = NA cows fed $0 \mathrm{~kg} / \mathrm{d}$ of concentrate DM; NA3 = NA cows fed $3 \mathrm{~kg} / \mathrm{d}$ of concentrate DM; NA6 = NA cows fed $6 \mathrm{~kg} / \mathrm{d}$ of concentrate DM.

${ }^{3}$ Standard error of the difference.

${ }^{4} \mathrm{~L}=$ linear contrast; $\mathrm{Q}=$ quadratic contrast; $\mathrm{G} \times \mathrm{D}=$ genotype $\times$ diet interaction.

${ }^{5}$ One week postcalving.

${ }^{6} 1$ to 10 scale (Macdonald and Roche, 2004).

${ }^{7}$ Immediately prior to calving.

genotypes; however, during the mating period, NA HF lost $(P<0.05)$ BCS and NZ gained BCS. During the extended-lactation mating period, NA HF had a lower $(P<0.001)$ BCS, but both genotypes gained a similar amount of BCS during mating (Table 4).

\section{Diet and Extended Lactation}

Supplementation with increasing levels of concentrate for an extended lactation produced a linear increase $(P<0.05)$ in yields of milk, milk protein, and milk solids; BW and BCS gain during lactation; final
BW and BCS at dry-off; and a linear decrease $(P<$ 0.001 ) in milk fat content (Tables 2 and 3). Milk solids, as a percentage of $\mathrm{BW}$, increased $(P<0.05)$ quadratically with supplementation. Supplementation did not significantly change DIM (Table 2) and reproductive parameters (data not presented).

\section{Genotype $\times$ Diet Interaction During Extended Lactation}

A genotype $\times$ diet linear interaction was detected for milk, milk protein, and milk solids yield (kg/cow and as a percentage of BW; Table 2).

Table 4. Mean reproductive performance and BCS of New Zealand (NZ) and North American (NA) HolsteinFriesians during a normal ${ }^{1}$ vs. extended ${ }^{2}$ lactation mating

\begin{tabular}{|c|c|c|c|c|c|c|c|}
\hline \multirow[b]{3}{*}{ Item } & \multicolumn{4}{|c|}{ Mating season } & \multirow[b]{3}{*}{$\mathrm{SED}^{3}$} & \multirow{2}{*}{\multicolumn{2}{|c|}{$P$-value }} \\
\hline & \multicolumn{2}{|c|}{ Normal } & \multicolumn{2}{|c|}{ Extended } & & & \\
\hline & NZ & NA & NZ & NA & & Normal & Extended \\
\hline \multicolumn{8}{|l|}{ Reproduction } \\
\hline 21 -d submission rate, $\%$ & 93 & 59 & 86 & 85 & 10 & $<0.01$ & NS \\
\hline First-service conception rate, $\%$ & 38 & 19 & 59 & 48 & 13 & 0.12 & NS \\
\hline 42-d pregnancy rate, $\%$ & 62 & 26 & 79 & 56 & 12 & $<0.01$ & $<0.05$ \\
\hline Final nonpregnancy rate, $\%$ & 14 & 48 & 3 & 30 & 11 & $<0.01$ & $<0.01$ \\
\hline \multicolumn{8}{|l|}{$\mathrm{BCS}^{4}$} \\
\hline At planned start of mating & 4.51 & 4.03 & 6.98 & 5.04 & 0.37 & NS & $<0.001$ \\
\hline Change during mating & 0.19 & -0.34 & 0.64 & 0.73 & 0.21 & $<0.05$ & NS \\
\hline
\end{tabular}

${ }^{1}$ Reproductive performance spring 2003 mating (planned start of mating $84 \mathrm{~d}$ after planned start of calving).

${ }^{2}$ Reproductive performance of the same cow's spring 2004 mating (planned start of mating $451 \mathrm{~d}$ after planned start of calving).

${ }^{3}$ Standard error of the difference.

${ }^{4} 1$ to 10 scale (Macdonald and Roche, 2004). 
Table 5. Annualized ${ }^{1}$ DIM and yields of milk, milk solids (fat + protein), protein and fat, and the ratio of annualized extended lactation vs. normal ${ }^{2}$ lactations for New Zealand (NZ) and North American (NA) Holstein-Friesians grazing pasture and fed 0, 3, or $6 \mathrm{~kg} / \mathrm{d}$ of concentrate DM during extended ${ }^{3}$ lactation

\begin{tabular}{|c|c|c|c|c|c|c|c|c|c|c|c|}
\hline \multirow[b]{2}{*}{ Item } & \multicolumn{6}{|c|}{ Treatment ${ }^{4}$} & \multirow[b]{2}{*}{$\mathrm{SED}^{5}$} & \multicolumn{4}{|c|}{$P$-value ${ }^{6}$} \\
\hline & NZ0 & NZ3 & NZ6 & NA0 & NA3 & NA6 & & Genotype & $\operatorname{Diet}_{L}$ & $\operatorname{Diet}_{Q}$ & $\mathrm{G} \times \mathrm{D}_{\mathrm{L}}$ \\
\hline \multicolumn{12}{|l|}{ Annualized production } \\
\hline Milk, kg/cow & 4,454 & 5,465 & 4,966 & 5,407 & 6,981 & 7,724 & 550.9 & $<0.01$ & $<0.01$ & 0.13 & $<0.05$ \\
\hline Milk solids, ${ }^{7} \mathrm{~kg} / \mathrm{cow}$ & 381 & 460 & 395 & 441 & 555 & 590 & 44.9 & $<0.01$ & $<0.05$ & 0.07 & $<0.05$ \\
\hline Milk fat, kg/cow & 212 & 252 & 210 & 240 & 292 & 305 & 26.2 & $<0.01$ & 0.12 & 0.08 & 0.07 \\
\hline Milk protein, kg/cow & 170 & 207 & 185 & 201 & 262 & 284 & 19.6 & $<0.01$ & $<0.01$ & 0.08 & $<0.05$ \\
\hline Milk, kg/cow & 0.75 & 0.79 & 0.71 & 0.85 & 0.93 & 0.88 & 0.05 & $<0.01$ & NS & $<0.05$ & NS \\
\hline Milk solids, ${ }^{7} \mathrm{~kg} / \mathrm{cow}$ & 0.78 & 0.83 & 0.75 & 0.89 & 1.00 & 0.94 & 0.06 & $<0.01$ & NS & $<0.05$ & NS \\
\hline Milk fat, kg/cow & 0.77 & 0.83 & 0.75 & 0.88 & 0.98 & 0.95 & 0.06 & $<0.01$ & NS & $<0.05$ & NS \\
\hline Milk protein, kg/cow & 0.79 & 0.83 & 0.73 & 0.91 & 1.02 & 0.94 & 0.06 & $<0.01$ & NS & $<0.05$ & NS \\
\hline
\end{tabular}

${ }^{1}$ Production during the 24-mo calving interval divided by $2 \mathrm{yr}$ to give an annual production.

${ }^{2}$ Production during the period from calving to the theoretical dry-off date in a 12 -mo calving interval system (calculated as $296 \pm 24$ DIM).

${ }^{3}$ The period from calving to actual dry-off date in a 24-mo calving interval system.

${ }^{4}$ Treatment: NZ0 = NZ cows fed $0 \mathrm{~kg} / \mathrm{d}$ of concentrate DM; NZ3 = NZ cows fed $3 \mathrm{~kg} / \mathrm{d}$ of concentrate DM; NZ6 = NZ cows fed $6 \mathrm{~kg} / \mathrm{d}$ of concentrate DM; NA0 = NA cows fed $0 \mathrm{~kg} / \mathrm{d}$ of concentrate DM; NA3 = NA cows fed $3 \mathrm{~kg} / \mathrm{d}$ of concentrate DM; NA6 = NA cows fed $6 \mathrm{~kg} / \mathrm{d}$ of concentrate DM.

${ }^{5}$ Standard error of the difference.

${ }^{6} \mathrm{~L}=$ linear contrast; $\mathrm{Q}=$ quadratic contrast; $\mathrm{G} \times \mathrm{D}=$ genotype $\times$ diet interaction.

${ }^{7}$ Fat + protein yield.

\section{Annualized Production Yields}

Genotype and diet effects on the annualized yields of milk, milk fat, milk protein, and milk solids produced during a 24-mo calving interval (Table 5) were similar to those presented in Table 2. Annualized yields of milk, milk protein, and milk solids were lower $(P<0.05$; 18,13 , and $13 \%$, respectively) than achieved in normal lactations. On an annualized basis, NA HF had more $(P<0.05)$ DIM and higher $(P<0.01)$ yields of milk, fat, protein, and milk solids in the extended-lactation system, compared with a normal lactation, than did NZ HF. On an annualized basis, supplementation produced a quadratic increase $(P<0.05)$ in yields of milk, fat, protein, and milk solids in the extended-lactation system compared with a normal lactation (Table 5).

\section{Lactation Profile}

The lactation profile of milk and milk solids production, milk fat, and milk protein content are presented in Figures 1 and 2. Milk and milk solids yields declined throughout lactation, but increased during the second spring to a varying extent across treatments. Between 360 and 430 DIM (July 23 and October 1, 2004), NA $\mathrm{HF}$ increased $(P<0.001)$ milk yield by $5.5 \mathrm{~kg} / \mathrm{d}$ (from 14.7 to $20.2 \mathrm{~kg} / \mathrm{d}$ ) compared with $1.6 \mathrm{~kg} / \mathrm{d}$ (10.8 to 12.5 $\mathrm{kg} / \mathrm{d}$ ) for NZ HF (Table 6). North American HF responded during the second spring with a greater increase $(P<0.001)$ in milk solids $(0.38$ vs. $0.06 \mathrm{~kg} / \mathrm{d})$ compared with NZ HF. The increase in milk yield during this second spring period was smaller $(P<0.001)$ at high rates of supplementation; however, a genotype $\times$ diet interaction indicated that during the second spring, NA HF increased milk and milk solids yields, and NZ HF reduced milk and milk solids yields when fed $6 \mathrm{~kg} /$ d of concentrate DM (Table 6).

Milk protein and fat content remained high from 300 DIM through to the end of lactation (Figure 2). Genotype differences in milk protein content present during the first 300 DIM were not observed during the extended phase of lactation (Figure 2 and Table 2). Genotype and diet differences in milk fat content present during the first 300 DIM continued to be apparent until drying off (Figure 2 and Table 2). After a decline in early lactation, BW and BCS increased steadily on all treatments throughout extended lactation, with genotype and diet effects becoming more pronounced with advancing stage of lactation (Figure 3 and Table 3 ).

\section{DISCUSSION}

This study demonstrated that milking cows for 2-yr lactations (24-mo calving interval) is possible on pasture-based diets, with some cow genotype and diet combinations experiencing no loss of annualized production (e.g., NA HF fed $3 \mathrm{~kg} / \mathrm{d}$ of concentrate DM), and other genotype and diet combinations experiencing large production losses (e.g., NZ HF receiving no supplementa- 


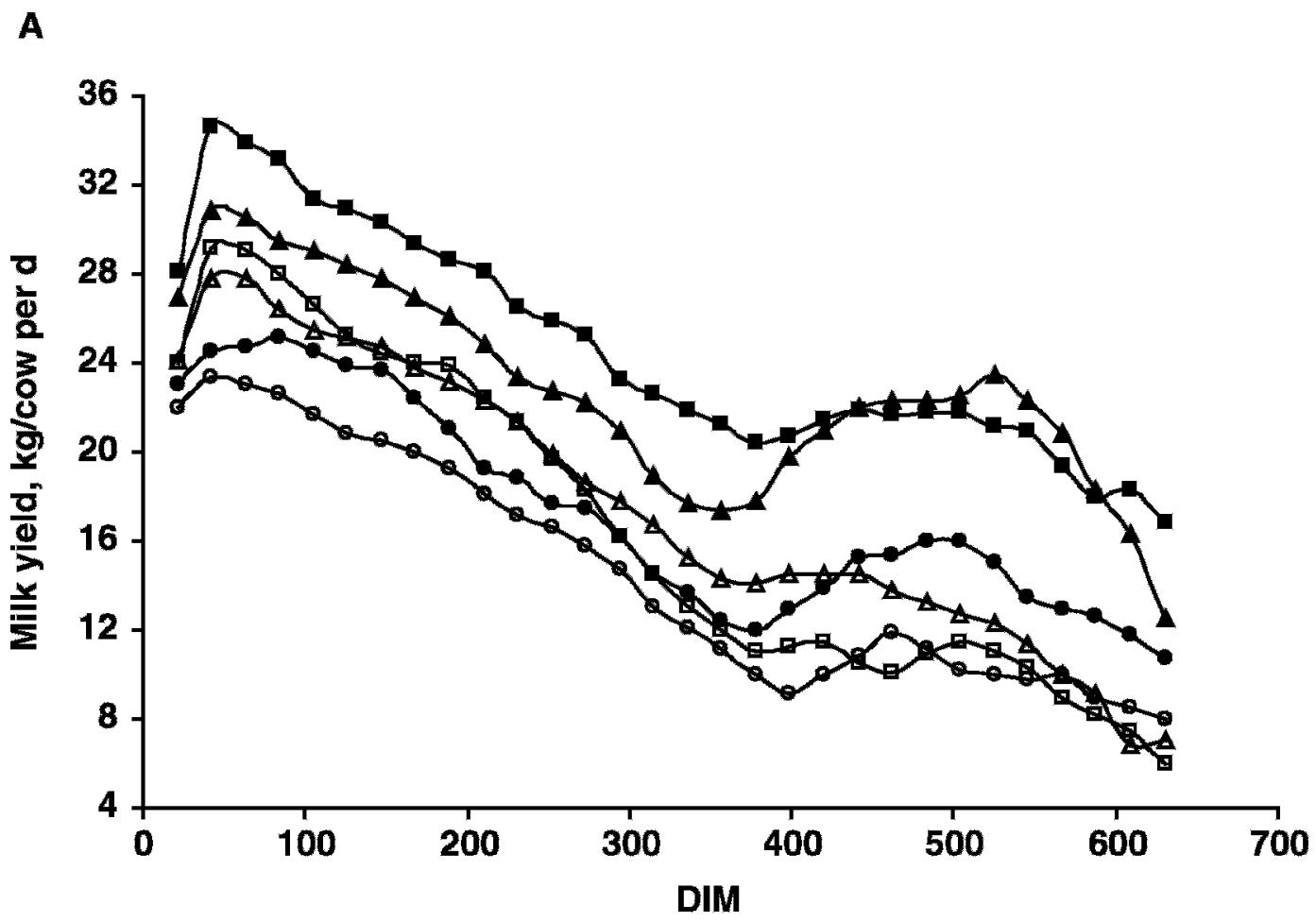

B

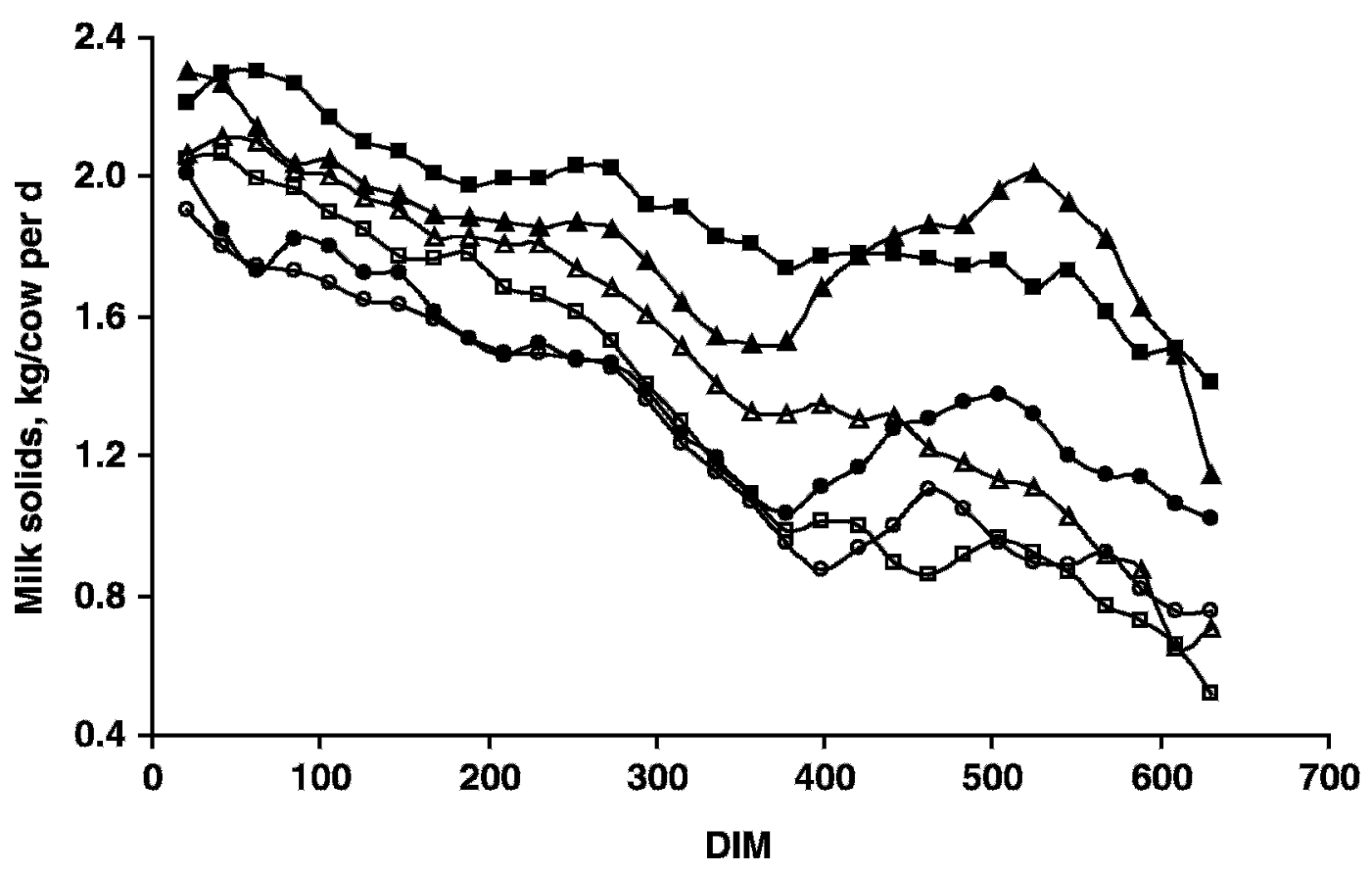

Figure 1. A) Milk yield and B) milk solids (fat + protein) yield of New Zealand (open symbols) and North American (closed symbols) Holstein-Friesians grazing pasture and fed $0(\bigcirc, \boldsymbol{\bullet}), 3(\triangle, \mathbf{\Delta})$, or $6(\square, \mathbf{\square}) \mathrm{kg} / \mathrm{d}$ of concentrate DM during extended lactation.

tion). This presents a unique application of extendedlactation technology, because most previous studies have been of 18-mo calving intervals in systems with confined feeding and high levels of production (Knight, 1998; Rehn et al., 2000; Arbel et al., 2001), and with access to bST (Van Amburgh et al., 1997) or frequent 


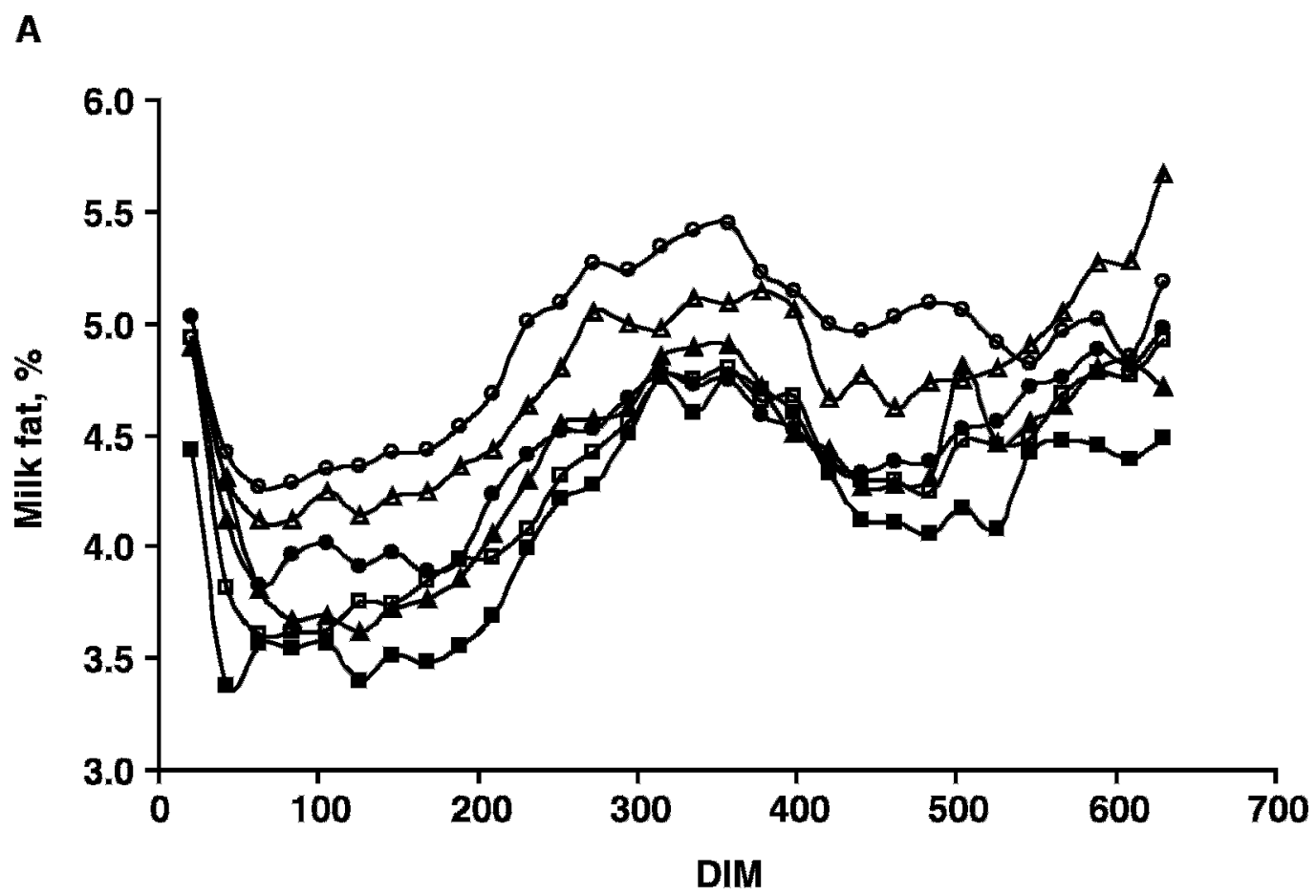

B

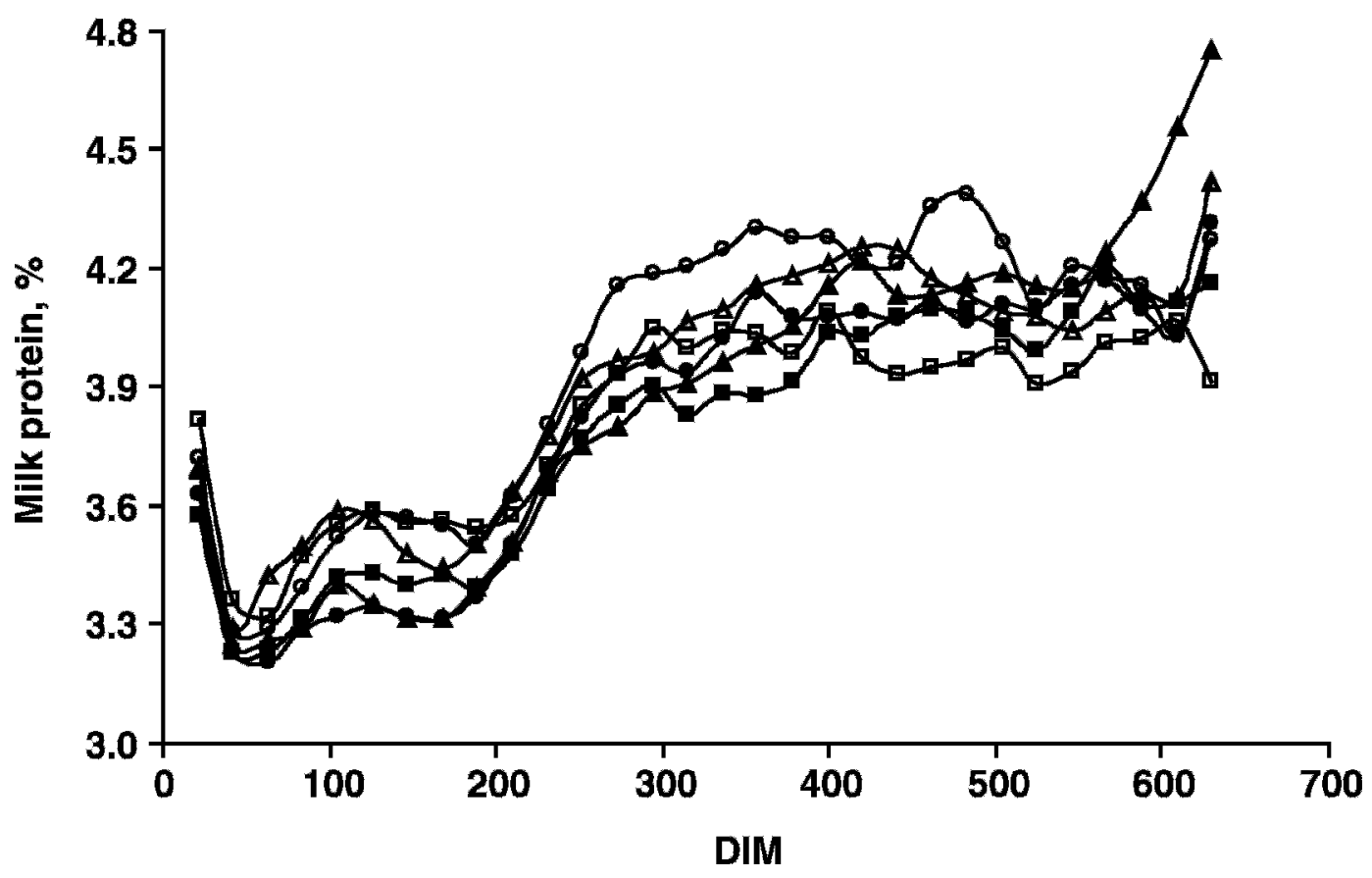

Figure 2. A) Milk fat content and B) milk protein content of New Zealand (open symbols) and North American (closed symbols) HolsteinFriesians grazing pasture and fed $0(\mathrm{O}, \boldsymbol{\bullet}), 3(\triangle, \mathbf{\Delta})$, or $6(\square, \boldsymbol{\square}) \mathrm{kg} / \mathrm{d}$ of concentrate DM during extended lactation.

milking (Osterman and Bertilsson, 2003). We have confirmed a recent report (Auldist et al., 2007) that cows managed under a pasture-based system of nutrition are able to sustain extended lactations with good persistency up to $22 \mathrm{mo}$.
Consistent with previous studies, the current study showed wide variation among individual cows in their ability to continue milking for longer than $300 \mathrm{~d}$. North American HF cows that are used in systems not confined to 12 -mo seasonal calving were more suited to 
Table 6. Change in milk and milk solids (fat + protein) yield during the second spring period (360 to 430 DIM: July 23, 2004, to October 1, 2004) for New Zealand (NZ) and North American (NA) Holstein-Friesians grazing pasture and fed 0,3 , or $6 \mathrm{~kg} / \mathrm{d}$ of concentrate DM during extended ${ }^{1}$ lactation

\begin{tabular}{|c|c|c|c|c|c|c|c|c|c|c|}
\hline \multirow[b]{2}{*}{ Item } & \multicolumn{6}{|c|}{ Treatment $^{2}$} & \multirow[b]{2}{*}{$\mathrm{SED}^{3}$} & \multicolumn{3}{|c|}{$P$-value } \\
\hline & $\mathrm{NZ0}$ & NZ3 & NZ6 & NA0 & NA3 & NA6 & & Genotype & Diet & $\mathrm{G} \times \mathrm{D}^{4}$ \\
\hline Milk, kg/d & 3.1 & 2.1 & -0.3 & 5.0 & 7.5 & 3.9 & 1.81 & $<0.001$ & $<0.001$ & $<0.05$ \\
\hline Milk solids ${ }^{5} \mathrm{~kg} / \mathrm{d}$ & 0.21 & 0.10 & -0.13 & 0.38 & 0.56 & 0.22 & 0.156 & $<0.001$ & $<0.001$ & $<0.05$ \\
\hline
\end{tabular}

\footnotetext{
${ }^{1}$ The period from calving to actual dry-off date in a 24-mo calving interval system.

${ }^{2}$ Treatment: NZ0 = NZ cows fed $0 \mathrm{~kg} / \mathrm{d}$ of concentrate DM; NZ3 = NZ cows fed $3 \mathrm{~kg} / \mathrm{d}$ of concentrate DM; NZ6 = NZ cows fed $6 \mathrm{~kg} / \mathrm{d}$ of concentrate DM; NA0 = NA cows fed $0 \mathrm{~kg} / \mathrm{d}$ of concentrate DM; NA3 = NA cows fed $3 \mathrm{~kg} / \mathrm{d}$ of concentrate DM; NA6 = NA cows fed $6 \mathrm{~kg} / \mathrm{d}$ of concentrate DM.

${ }^{3}$ Standard error of the difference.

${ }^{4}$ Genotype $\times$ diet interaction.

${ }^{5}$ Fat + protein yield.
}

extended lactation, with $48 \%$ milking through until the final dry-off date compared with $14 \%$ of NZ HF cows, although both genotypes could milk for $500 \mathrm{~d}$, after which cows began to be dried off. Auldist et al. (2007) observed that more than $95 \%$ of cows were able to lactate for at least 16 mo in pasture-based systems.

Although this study was limited in the number of animals representing each genotype, sires and cows were carefully selected to represent high-usage genetics. Production and fertility results during the calculated 10-mo lactation were consistent with similarly designed, multiyear comparison studies of seasonally calving NZ HF and NA HF cows (Horan et al., 2005; Macdonald et al., 2007), and with larger (104,862 lactations) comparison studies of NZ HF and NA HF using data collected over 12 yr (Harris and Kolver, 2001). Nonetheless, as with any population, there are sires and cows that are not represented by the genetics used in this study.

Consistent with previous studies, high concentrations of milk fat and protein were maintained during the extended phase of lactation, which offset the decline in milk volume. This suggests that extended lactations may be more suited to suppliers of manufacturing milk than liquid milk suppliers. Milk protein was maintained at approximately $4.1 \%$ from 300 to 600 DIM. This was irrespective of genotype or feeding treatment and showed the dominance of stage of lactation on milk composition. In Australia and New Zealand, dairy farmers receive payment for the milk solids (fat + protein) supplied, with protein being 3 times the value of fat. Because milk protein was elevated to a greater extent than milk fat during the current extended-lactation study, farmers would have received a small increase (1.5\%) in the milk price throughout the entire lactation compared with that for milk produced in the first $300 \mathrm{~d}$.

The current study encompassed a range of cow genotype and nutrition treatments. For some of these combi- nations (NA HF fed $3 \mathrm{~kg} / \mathrm{d}$ of concentrate DM), lactations of $600 \mathrm{~d}$ could be achieved with no loss of milk solids production when compared on an annual basis with a normal 10-mo lactation. Cows with extended lactations spend less time at peak production but more time lactating, so annualized production figures are the most meaningful method of comparing extended-lactation performance with traditional systems. Recently, Auldist et al. (2007) reported that annualized milk solids were reduced by $0,0.4,5$, and $7 \%$ when cows in pasture-based systems underwent lactations of 13, 16, 19 , or $22 \mathrm{mo}$, compared with cows producing $497 \mathrm{~kg}$ of milk solids/cow in 12-mo calving interval systems. We similarly report a $6 \%$ milk solids reduction by the NA6 treatment, which used a similar cow genotype and level of supplementation during a 24-mo calving interval.

In confinement feeding systems, Osterman and Bertilsson (2003) reported that cows with an 18-mo calving interval produced the same amount of ECM per day as cows with a 12-mo calving interval. In the present study, despite lower daily milk yields during extended lactation, the difference in annualized milk solids production compared with 12-mo calving systems was reduced by having fewer nonlactating days each year, and by a higher milk fat and protein content. Therefore, the extended-lactation concept may be suited to lower production, pasture-based systems, because less milk is forgone in extended lactations because of lower peak milk yields during the early part of traditional 10-mo lactations, compared with more intensive feeding systems.

Annualized milk solids reductions of 17 to $25 \%$ incurred by NZ HF cows in the current study likely reflected the lack of selection pressure for production outside a seasonal 12-mo calving system. Reflective of this was the large increase in BW and BCS of NZ HF during the 2-yr lactation. Although many NZ HF cows continued to produce acceptable yields during extended lacta- 

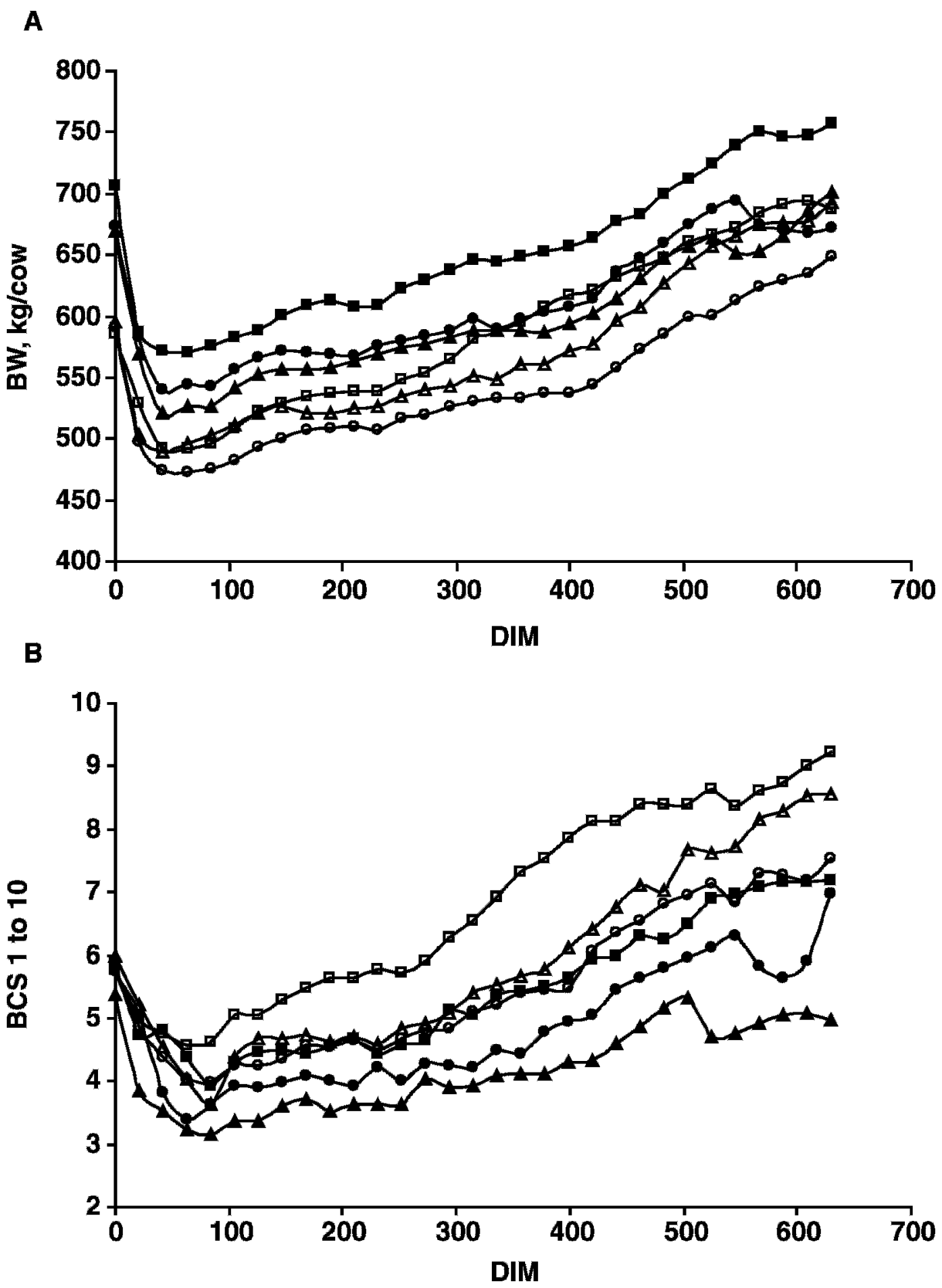

Figure 3. A) Body weight and B) BCS (1 to 10 scale) of New Zealand (open symbols) and North American (closed symbols) HolsteinFriesians grazing pasture and fed $0(\bigcirc, \bullet), 3(\triangle, \mathbf{\Delta})$, or $6(\square, \boldsymbol{\square}) \mathrm{kg} / \mathrm{d}$ of concentrate DM during extended lactation.

tion, the excessive body condition presents a management issue both for the current season and the following season. This suggests that both persistency of milk production and maintenance of acceptable body condition will be important for future selection of cows suitable for extended lactations.

In the current study, annualized milk solids production may be underestimated, because the nonpregnant 
cows used would be expected to produce more during the first 10 mo of lactation than seasonally calving cows that are pregnant for much of the lactation. Based on estimates of production losses caused by pregnancy in a 305-d lactation (Roche, 2003), the effect is likely small, increasing the ratio of annualized:normal milk solids by 0.01 to 0.02 (Table 5). Yet the annualized production of higher producing NA HF may be underestimated to a greater extent than that of NZ HF (Table 2).

A second lactation peak was evident in some of the treatments during the second spring. This peak was more evident with NA HF cows and with cows on the 0 and $3 \mathrm{~kg} / \mathrm{d}$ of concentrate DM treatments, compared with the $6 \mathrm{~kg} / \mathrm{d}$ of concentrate DM treatments. This suggests that the second spring peak may be a function of feeding, most likely attributable to the level of nutrition during the preceding winter. Similarly, the greater second lactation peak exhibited by NA HF may reflect a greater feed deficit experienced during the preceding winter relative to NZ HF. This supports the findings of Auldist et al. (2007), who reported no second-lactation peak with cows and diets similar to the NA6 treatment of the current experiment.

The direct comparison of reproductive performance during extended lactation and normal lactation is confounded by year (different seasons, different breeding policies), and the ability to test fertility effects was limited. Nonetheless, the greater fertility of the NZ HF was apparent, and is consistent with previous studies of 12-mo calving interval systems (Harris and Kolver, 2001; Kolver et al., 2002, 2005). The results suggest that the differences in submission rate, pregnancy rate, and final nonpregnancy rate between the 2 genotypes were reduced by the removal of the 12-mo calving interval constraint. This is consistent with the findings of Larsson and Berglund (2000), who studied 15- and 18mo calving intervals and reported a lower rate of anestrous, a higher conception rate, and reduced culling because of fertility problems, and with Schindler et al. (1991), who reported a higher conception rate with 15mo calving intervals. In the current study, all but 4 cows were confirmed as cycling at the start of mating (451 d after calving), were in positive energy balance, and had a desirable body condition. Still, a final nonpregnancy rate of $30 \%$ was recorded for the NA HF. The results suggest that a factor(s) other than negative energy balance contributes to the infertility problems in NA HF cows in grazing systems. In intensive feeding systems, Lucy (2001) observed that the decline in HF fertility was multifactorial and not associated entirely with negative energy balance. These results point to an underlying subfertility that does not appear to be completely addressed by improving energy balance through feeding or increasing the interval between calving and mating.

In conclusion, based on the genetics represented in this study, milking cows for productive 2-yr lactations appears feasible on pasture-based diets. Annualized milk solids production ranged from 75 to $100 \%$ of normal 10-mo lactations, and was dependent on the genotype of the cow and level of supplementation. Extended lactations result in milk with a higher fat and protein content and cows with a higher BW and BCS. With appropriate cow genetics and feed management, reduced reproductive performance may be ameliorated in high-producing dairy cows without sacrificing milk solids production. Further work is underway to develop appropriate cow selection measures, and to evaluate the profitability and risk of pasture-based, extendedlactation dairying systems.

\section{ACKNOWLEDGMENTS}

The authors gratefully acknowledge the contribution and dedication of the Dexcel Lye Farm staff, especially A. Napper and B. Sugar, as well as B. Dow for statistical analysis and C. V. C Phyn for critical review. This research was funded by New Zealand dairy farmers through Dairy InSight (Wellington, New Zealand).

\section{REFERENCES}

Arbel, R., Y. Bigun, E. Ezra, H. Sturman, and D. Hajman. 2001. The effect of extended calving intervals in high-yielding lactating cows on milk production and profitability. J. Dairy Sci. 84:600-608.

Auldist, M. J., G. O’Brien, D. Cole, K. L. Macmillan, and C. Grainger. 2007. Effects of varying lactation length on milk production capacity of cows in pasture-based dairying systems. J. Dairy Sci. 90:3234-3241.

Borman, J. M., K. L. Macmillan, and J. Fahey. 2004. The potential for extended lactations in Victorian dairying: A review. Aust. J. Exp. Agric. 44:507-519.

Harris, B. L., J. M. Clark, and R. G. Jackson. 1996. Across breed evaluation of dairy cattle. Proc. N. Z. Soc. Anim. Prod. 56:12-15.

Harris, B. L., and E. S. Kolver. 2001. A review of Holsteinization on intensive pastoral dairy farming in New Zealand. J. Dairy Sci. 84(E. Suppl.):E56-E61.

Horan, B., P. Dillon, P. Faverdin, L. Delaby, F. Buckley, and M. Rath. 2005. The interaction of strain of Holstein-Friesian cows and pasture based feed systems on milk yield, body weight and body condition score. J. Dairy Sci. 88:1231-1243.

Knight, C. H. 1998. Extended lactation. Pages 30-39 in Hannah Research Institute Yearbook 1998. Hannah Research Institute, Ayr, Scotland.

Kolver, E. S., P. W. Aspin, and J. R. Roche. 2005. Influence of dairy cow genotype on milksolids, body condition, and reproduction response to concentrate supplementation. Proc. N. Z. Soc. Anim. Prod. 65:46-52.

Kolver, E. S., J. R. Roche, M. J. de Veth, P. L. Thorne, and A. R. Napper. 2002. Total mixed rations versus pasture diets: Evidence for a genotype $\times$ diet interaction in dairy cow performance. Proc. N. Z. Soc. Anim. Prod. 62:246-251.

Larsson, B., and B. Berglund. 2000. Reproductive performance of cows with extended calving interval. Reprod. Dom. Anim. 35:277-280.

Lucy, M. C. 2001. Reproductive loss in high-producing dairy cattle: Where will it end? J. Dairy Sci. 84(E-Suppl.):E1277-E1293. 
Macdonald, K. A., and J. R. Roche. 2004. Condition scoring made easy. Pages 4-7 in Condition Scoring Dairy Herds. 1st ed. Dexcel Ltd., Hamilton, New Zealand.

Macdonald, K. A., L. R. McNaughton, G. A. Verkerk, J. W. Penno, L. Burton, D. Berry, P. Gore, J. A. S. Lancaster, and C. W. Holmes. 2007. A comparison of three strains of Holstein-Friesian grazed on pasture. Growth, development, and puberty. J. Dairy Sci. 90:3993-4003.

Macdonald, K. A., B. S. Thorrold, C. B. Glassey, C. W. Holmes, and J. E. Pryce. 2005. Impact of farm management decision rules on the production and profit of different strains of Holstein-Friesian dairy cows. Proc. N. Z. Soc. Anim. Prod. 65:40-45.

Osterman, S., and J. Bertilsson. 2003. Extended calving interval in combination with milking two or three times per day: Effects on milk production and milk composition. Livest. Prod. Sci. 82:139-149.

Rehn, H., B. Berglund, U. Emanuelson, G. Tengroth, and J. Philipsson. 2000. Milk production in Swedish dairy cows managed for calving intervals of 12 and 15 months. Acta Agric. Scand. Anim. Sci. 50:263-271.

Roche, J. R. 2003. Effect of pregnancy on milk production and bodyweight from identical twin study. J. Dairy Sci. 86:777-783.
Roche, J. R., D. P. Berry, and E. S. Kolver. 2006. Holstein-Friesian strain and feed effects on milk production, body weight, and body condition score profiles in grazing dairy cows. J. Dairy Sci. 89:3532-3543.

Rotz, C. A., D. L. Zartman, and K. L. Crandall. 2005. Economic and environmental feasibility of a perennial cow dairy farm. J. Dairy Sci. 88:3009-3019.

Schindler, H., S. Eger, M. Davidson, D. Ochowski, E. C. Schermerhorn, and R. H. Foote. 1991. Factors affecting response of groups of dairy cows managed for different calving-conception intervals. Theriogenology 36:495-503.

Thatcher, W. W., T. R. Bilby, J. A. Bartolome, F. Silvestre, C. R. Staples, and J. E. P. Santos. 2006. Strategies for improving fertility in the modern dairy cow. Theriogenology 65:30-44.

Van Amburgh, M. E., D. M. Galton, D. E. Bauman, and R. W. Everett. 1997. Management and economics of extended calving intervals with use of bovine somatotropin. Livest. Prod. Sci. 50:15-28.

Xu, Z. Z., L. J. Burton, and K. L. Macmillan. 1996. Reproductive performance of lactating dairy cows following oestrus synchronisation with progesterone, oestradiol and prostaglandin. N. Z. Vet. J. 44:99-104. 